\title{
Simpanan Karbon pada Ekosistem Lamun di Perairan Alang - Alang dan Perairan Pancuran Karimunjawa, Jawa Tengah
}

\author{
Kiki Pebli Novita Dewi Fifianingrum*, Hadi Endrawati, Ita Riniatsih \\ Departemen IImu Kelautan, Fakultas Perikanan dan IImu Kelautan, Universitas Diponegoro \\ JI. Prof. H. Soedarto S.H, Tembalang, Semarang, Jawa Tengah 50275 Indonesia \\ *Corresponding author, e-mail : kikipebli21@gmail.com
}

\begin{abstract}
ABSTRAK : Emisi gas $\mathrm{CO} 2$ berkontribusi tinggi terhadap pemanasan global. Karbon merupakan unsur yang berasal dari pengikatan $\mathrm{CO} 2$ oleh tumbuhan melalui fotosintesis. Hutan mengalami penurunan sehingga sektor laut perlu di berdayakan. Kemampuan lamun mengikat karbon dikenal sebagai blue carbon. Tujuan penelitian adalah mengetahui estimasi karbon ekosistem lamun di Perairan Alang - Alang dan Perairan Pancuran Pulau Karimunjawa, sehingga dapat mengurangi pemanasan global. Metode penelitian di lapangan yaitu metode SeagrassWatch dan di laboratorium yaitu Metode Loss of Ignition (LOI). Hasil spesies lamun di lokasi penelitian yaitu Thalassia hemprichii, Enhalus acoroides, Cymodocea rotundata, Cymodocea serrulata, Halodule ovalis, dan Halodule uninervis. Kerapatan lamun pada Lokasi 1 berkisar $84,00 \mathrm{tgk} / \mathrm{m}^{2}-202,91$ $\mathrm{tgk} / \mathrm{m}^{2}$ dan pada Lokasi 2 berkisar $105,09 \mathrm{tgk} / \mathrm{m}^{2}-285,09 \mathrm{tgk} / \mathrm{m}^{2}$. Biomassa lamun terbesar pada Lokasi 1 yaitu Enhalus acoroides dengan nilai $1811,38 \mathrm{gbk} / \mathrm{m}^{2}$ dan biomassa lamun terkecil Cymodocea rotundata dengan nilai $25,72 \mathrm{gbk} / \mathrm{m}^{2}$. Biomassa lamun terbesar pada Lokasi 2 yaitu Enhalus acoroides dengan nilai $733,20 \mathrm{gbk} / \mathrm{m}^{2}$ dan biomassa lamun terkecil Halodule uninervis dengan nilai $0,47 \mathrm{gbk} / \mathrm{m}^{2}$. Karbon lamun terbesar pada Lokasi 1 yaitu Enhalus acoroides dengan nilai $35.538,12 \mathrm{gC} / \mathrm{m}^{2}$, dan terkecil Cymodocea rotundata dengan nilai $473,24 \mathrm{gC} / \mathrm{m}^{2}$. Karbon lamun terbesar pada Lokasi 2 yaitu Thalassia hemprichii dengan nilai $14.309,39 \mathrm{gC} / \mathrm{m}^{2}$ dan terkecil Halodule uninervis dengan nilai $5,80 \mathrm{gC} / \mathrm{m}^{2}$. Karbon sedimen pada Lokasi 1 berkisar $1,581 \mathrm{gC} / \mathrm{m}^{2}-$ $1,871 \mathrm{gC} / \mathrm{m}^{2}$ dan Lokasi 2 berkisar $0,841 \mathrm{gC} / \mathrm{m}^{2}-1,45 \mathrm{gC} / \mathrm{m}^{2}$. Kandungan terbesar karbon terdapat pada bagian bawah substrat, karena bagian atas substrat karbon mudah hilang oleh faktor lingkungan (gelombang, arus, dan ulah manusia), sedangkan pada bawah substrat karbon terakumulasi baik.
\end{abstract}

Kata kunci : Karbon; Ekosistem; Lamun; sedimen

\section{Carbon Deposit Estimation in Seagrass Ecosystem in Alang - Alang and Pancuran Waters Karimunjawa, Central Java}

ABSTRACT: $\mathrm{CO} 2$ contribute high to global warming. Carbon is an element derived from binding of $\mathrm{CO} 2$ by plants through photosynthesis. Forests have declined so the marine sector (blue carbon) needs to be priority. The purpose this study was to determine the carbon seagrass ecosystem estimation in Alang - Alang and Pancuran Waters Karimunjawa Island, so can to reduce global warming. The research method in the field is SeagrassWatch method and in the laboratory is Loss of Ignition Method. The results species at location were Thalassia hemprichii, Enhalus acoroides, Cymodocea rotundata, Cymodocea serrulata, Halodule ovalis, and Halodule uninervis. The density seagrass Location 1 is $84.00-202.91 \mathrm{tgk} / \mathrm{m}^{2}$ and Location 2 is $105.09-285.09 \mathrm{tgk} / \mathrm{m}^{2}$. The largest seagrass biomass at Location 1 is Enhalus acoroides with a value $1811.38 \mathrm{gbk} / \mathrm{m}^{2}$ and the smallest seagrass biomass Cymodocea rotundata with a value $25.72 \mathrm{gbk} / \mathrm{m}^{2}$. The largest seagrass biomass at Location 2 is Enhalus acoroides with a value $733.20 \mathrm{gbk} / \mathrm{m}^{2}$ and the smallest seagrass biomass Halodule uninervis with a value $0.47 \mathrm{gbk} / \mathrm{m}^{2}$. The biggest seagrass carbon at Location 1 is Enhalus acoroides with a value $35,538.12 \mathrm{gC} / \mathrm{m}^{2}$, and the smallest Cymodocea rotundata with a value $473.24 \mathrm{gC} / \mathrm{m}^{2}$. The biggest seagrass carbon at Location 2 is Thalassia hemprichii with a value $14,309.39 \mathrm{gC} / \mathrm{m}^{2}$ and the smallest Halodule uninervis with a value 5.80 $\mathrm{gC} / \mathrm{m}^{2}$. Sediment carbon at Location $11.581-1.871 \mathrm{gC} / \mathrm{m}^{2}$ and Location $20.841-1.45 \mathrm{gC} / \mathrm{m}^{2}$. The 
largest carbon content in bellow substrate, because on above substrate easily lost by environmental factors, while in the bellow substrate carbon accumulates well.

Keywords : Carbon; Seagrass; Ecosystem; sediment

\section{PENDAHULUAN}

Lapisan udara yang menyelimuti atmosfer bumi dari tahun ke tahun semakin panas. Sektor industri dan kendaraan berbahan bakar minyak menyebabkan peningkatan emisi gas rumah kaca (Rahadiarta et al., 2019). Emisi gas rumah kaca yang paling besar adalah CO2. Gas CO2 menjadi perhatian penting karena memiliki kontribusi yang paling tinggi terhadap kandungan gas rumah kaca, yaitu sebesar $55 \%$ dari emisi karbon yang dihasilkan oleh aktivitas manusia (Septiani et al., 2018). Keberadaannya di atmosfer yang semakin meningkat dan minimnya pengikatan oleh tumbuhan hijau dapat menyebabkan pemanasan global.

Karbon (C) merupakan unsur yang berasal dari pengikatan $\mathrm{CO} 2$ oleh tumbuhan dan di dalam biomassa tanaman melalui proses fotosintesis (Rahadiarta et al., 2019). Fenomena ini menyebabkan perubahan iklim yang berdampak pada meningkatnya suhu ekstrim, banjir, topan, badai, kekeringan dan naiknya permukaan laut hingga makhluk hidup (manusia dan hewan) merasakan dampak negatif langsung dari pemanasan global (Nordlund et al., 2016). Gas CO2 dapat larut dalam air sehingga dapat di serap oleh tumbuhan air. Peningkatan emisi gas $\mathrm{CO} 2$ harus di imbangi dengan peningkatan penyerapan oleh tanaman dengan cara fotosintesis.

Masyarakat pada umumnya hanya mengetahui bahwa hutan dan tanaman darat saja yang dapat berfotosintesis. Hutan telah mengalami penurunan dari tahun ke tahun karena pembakaran dan alih fungsi lahan. Secara geografis laut memiliki luas lebih besar dibandingkan daratan dengan perbandingan 70\% : 30\%, sehingga laut menjadi penting untuk dimanfaatkan karena terdapat plankton dan lamun yang dapat berfotosintesis. Padang lamun adalah vegetasi yang memiliki potensi besar dalam mengurangi dampak emisi di lingkungan (Nordlund et al., 2016).

Laut memiliki peranan yang penting dalam siklus karbon, sekitar 93\% CO2 di bumi disimpan dalam lautan (Rahadiarta et al., 2019). UNEP, FAO dan UNESCO pada tahun 2009 telah memperkenalkan konsep blue carbon yaitu menekankan pentingnya ekosistem laut dan pesisir sebagai pengendali iklim (Hartati et al., 2017). Mangrove dan Lamun adalah tumbuhan laut yang memiliki kemampuan sama dengan tumbuhan darat dalam menyerap $\mathrm{CO} 2$ dan menghasilkan $\mathrm{O} 2$. Kemampuan lamun dalam melakukan fotosintesis memanfaatkan $\mathrm{CO} 2$ dan menyimpannya dalam biomassa dikenal sebagai karbon biru (blue carbon) (Nordlund et al., 2016). Lamun merupakan tumbuhan Angiospermae, memiliki kemampuan beradaptasi di perairan yang berfluktuasi salinitas tinggi, hidup terbenam dalam air dan memiliki rhizoma, daun, akar (Graha et al., 2016).

Lamun terbagi atas dua bagian, yaitu lamun bagian atas (above ground) dan lamun bagian bawah (below ground). Lamun dalam melakukan fotosintesis memanfaatkan karbon inorganik yang terlarut di kolom air (dissolved inorganic carbon/DIC) sehingga lamun dapat mereduksi $\mathrm{CO} 2$ (Nordlund et al., 2016). Ekosistem padang lamun dapat menyimpan 83.000 metrik ton karbon dalam setiap kilometer persegi, lebih tinggi dibandingkan kemampuan hutan hujan tropis menyerap karbon yakni hanya sekitar 30.000 metrik ton $/ \mathrm{km}^{2}$. Potensi lamun sebagai karbon biru (blue carbon) terbesar pada bagian bawah lamun yang terdiri dari rhizome dan akar lamun (Septiyani et al., 2018).

Penyimpanan karbon pada lamun terakumulasi banyak pada sedimen, karena rhizoma dan daun mengalami banyak gangguan lingkungan. Masyarakat pada umumnya belum mengetahui apa itu lamun, sehingga pemahaman tentang manfaat lamun dan pentingnya melestarikan lamun masih rendah. Pertumbuhan dan kepadatan lamun sangat dipengaruhi oleh pola pasang surut, turbiditas, salinitas dan temperatur perairan, sedangkan kegiatan manusia di wilayah pesisir seperti perikanan, pembangunan perumahan, pelabuhan dan rekreasi dapat mempengaruhi eksistensi lamun (Tangke, 2010). Ekosistem karbon biru pesisir merupakan salah satu ekosistem yang paling terancam di Bumi, dengan sekitar 340.000 hingga 980.000 hektar ekosistem ini dihancurkan setiap tahunnya. Diperkiraka sampai dengan $67 \%$ dan sedikitnya $35 \%$ dan $29 \%$ dari 
seluruh cakupan global hutan bakau, rawa pasang surut, dan padang lamun, secara berurutan, telah hilang (Oreska et al., 2017). Penelitian tentang potensi penyimpanan karbon pada lamun masih sedikit. Oleh karena itu penting dilakukan penelitian estimasi simpanan karbon pada lamun agar masyarakat dapat mengetahui lamun dan manfaatnya serta dapat melestarikan ekosistem lamun sehingga meminimalisir emisi gas CO2 dan pemanasan global (Tangke, 2010).

\section{MATERI DAN METODE}

Materi yang digunakan dalam penelitian ini adalah kandungan karbon pada lamun dengan jenis yang berbeda dan sedimennya. Lamun diambil dengan pencabutan pada kedalaman penetrasi akar dan substrat diambil pada kedalaman akar lamun. Sampel lamun dan substrat di ambil dari Perairan Alang - Alang dan Perairan Pancuran Pulau Karimunjawa. Penelitian ini terbagi menjadi dua tahap, yaitu pengambilan data lapangan dan penelitian di laboratorium. Pengukuran kadar karbon yang terdapat di biomassa lamun beserta sedimennya di Laboratorium IImu Nutrisi Fakultas Peternakan dan Pertanian Universitas Diponegoro, sedangkan analisis ukuran dan tipe butir sedimen yang dilakukan di Laboratorium Sedimentologi Fakultas Perikanan dan Ilmu Kelautan, Universitas Diponegoro.

\section{HASIL DAN PEMBAHASAN}

Hasil biomassa menunjukkan bahwa $E$. acoroides memiliki nilai biomassa paling tinggi tetapi nilai kerapatannya tidak paling tinggi, hal ini karena $E$. acoroides memiliki ukuran morfologi paling besar. Menurut Mardiyanti et al., (2013), nilai biomassa dari suatu jenis lamun dipengaruhi oleh ukuran lamun. Ukuran yang besar menghasilkan biomassa yang tinggi karena kemampuan

E. acoroides dalam menyimpan bahan organik hasil fotosintesis tinggi. T. hemprichii memiliki nilai biomassa cukup tinggi karena nilai kerapatannya paling tinggi. Kerapatan yang tinggi menghasilkan biomassa yang tinggi. Hal ini sesuai dengan pendapat Latuconsina et al. (2014), bahwa faktor yang mempengaruhi besarnya biomassa adalah morfologi lamun dan kerapatan lamun. $C$. serrulata dan $C$. rotundata berada dalam genus yang sama sehingga bentuk dan ukuran morfologinya hampir sama. Nilai kerapatan $C$. serrulata lebih tinggi dibandingkan $C$. rotundata. Sehingga perbedaan biomassanya disebabkan perbedaan nilai kerapatan bukan ukuran morfologi.

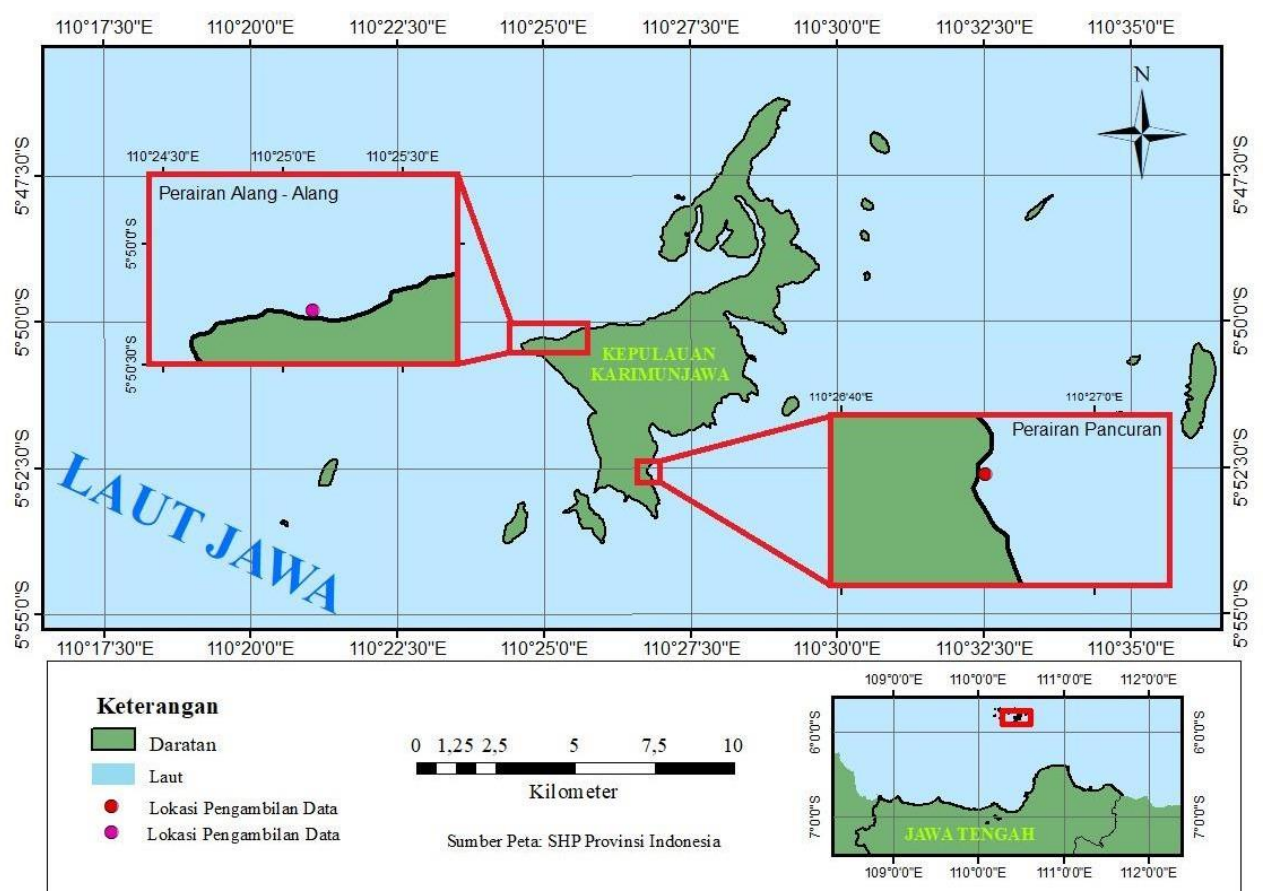

Gambar 1. Peta lokasi di Perairan Alang-Alang dan Perairan Pancuran Pulau Karimunjawa 
Hasil penelitian menunjukkan bahwa biomassa bawah substrat lebih tinggi dibandingkan atas substrat. Menurut Duarte dan Chiscano (1999), jika bagian bawah biomassanya besar maka bagian atas akan semakin kecil. Persentase biomassa bawah substrat $53 \%$ dan atas substrat $47 \%$, karena biomassa bawah substrat gabungan dari akar dan rhizome (Hartati et al., 2017). Hal ini sesuai dengan hasil penelitian bahwa biomassa bawah substrat lebih tinggi dibandingkan atas substrat. Nilai biomassa yang besar pada bawah substrat disebabkan oleh kelebihan karbohidrat yang disimpan pada akar dan rhizoma karena fiksasi karbon pada lamun yang melebihi kebutuhan metabolismenya (Duarte dan Cebrian, 1996). Rhizome merupakan jaringan lamun dengan morfologi besar sehingga mempunyai biomassa lebih tinggi dibandingkan jaringan lainnya. Hasil biomassa lamun di Perairan Alang-Alang dan Perairan Pancuran dapat dilihat pada Tabel 1. dan Tabel 2.

Tingginya nilai biomassa pada lamun bagian bawah substrat berhubungan dengan adanya efek positif dari tipe substrat organik terhadap perkembangan sistem penyerapan nutrien (Christon et al., 2012). Bahan organik yang terdapat pada substrat dasar perairan berasal dari jaringan organik tanaman, salah satunya lamun (Phillips dan Milchakova, 2015). Menurut Hemingga dan Duarte (2000), biomassa lamun lebih besar tersimpan pada bagian bawah dibandingkan atas substrat, hal ini karena rhizome mengandung banyak zat pati dan unsur hara dimana zat tersebut didapatkan dari hasil fotosintesis yang tersimpan di bagian bawah substrat, sehingga biomassanya lebih tinggi. Latuconsina et al. (2014), menyatakan bahwa lamunjenis $E$. acoroides dapat memiliki biomassa 6-10 kali lebih besar di bagian rhizome dibandingkan di bagian daun.

Biomassa paling rendah pada lokasi penelitian adalah $H$. ovalis dan $H$. uninervis karena persaingan nutrisi sehingga tidak dapat menunjang kehidupan yang dapat menghasilkan biomassa (Nordlund et al., 2016). Nilai biomassa yang berada dibawah substrat berasal dari nutrisi yang diserap oleh akar pada sedimen serta material organik hasil fotosintesis yang sebagian besar disimpan pada rhizome dan berkaitan erat dengan daya tancap lamun pada substrat untuk bertahan dari arus dan gelombang (Tasabaramo et al., 2015). Jenis sedimen mempengaruhi tingkat kerapatan lamun, karena sedimen berkaitan dengan perakaran tumbuhan lamun, kecerahan perairan dan ketersediaan nutrien dalam substrat. Jenis sedimen dapat mempengaruhi kekeruhan di perairan yang dapat berpotensi mengurangi penetrasi cahaya sehingga dapat mengganggu produktifitas primer padang lamun (Hartati et al., 2017).

Tabel 1. Biomassa Lamun Perairan Alang - Alang

\begin{tabular}{lccc}
\hline \multirow{2}{*}{ Spesies } & \multicolumn{3}{c}{ Total Biomassa perjaringan (gbk/m2) } \\
\cline { 2 - 4 } & Bawah Substrat & Atas Substrat & Total Keseluruhan \\
\hline Thalassia hemprichii & 375,83 & 97,41 & 473,23 \\
Enhalus acoroides & 1374,7 & 436,68 & 1811,38 \\
Cymodocea rotundata & 20,48 & 5,24 & 25,72 \\
Cymodocea serrulata & 102,64 & 20,44 & 123,08 \\
\hline
\end{tabular}

Tabel 2. Biomassa Lamun di Perairan Pancuran

\begin{tabular}{cccc}
\hline \multirow{2}{*}{ Spesies } & & \multicolumn{2}{c}{ Total Biomassa perjaringan (gbk/m2) } \\
\cline { 2 - 4 } & Bawah Substrat & Atas Substrat & Total Keseluruhan \\
\hline Thalassia hemprichii & 426,46 & 83,65 & 510,11 \\
Enhalus acoroides & 659,76 & 73,44 & 733,20 \\
Cymodocea rotundata & 102,38 & 58,09 & 160,48 \\
Cymodocea serrulata & 3,56 & 1,71 & 5,26 \\
Halodule uninervis & 0,41 & 0,06 & 0,47 \\
Halophila ovalis & 1,78 & 0,69 & 2,47 \\
\hline
\end{tabular}


Kandungan karbon pada lamun dipengaruhi oleh biomassa antar jenis ataupun antar jaringan (Graha, 2015). Semakin tinggi biomassa lamun maka kandungan karbonnya semakin meningkat, artinya kandungan karbon berbanding lurus dengan kandungan biomassa pada lamun (Phillips dan Milchakova, 2015). Hal ini sesuai dengan hasil penelitian bahwa E. acoroides memiliki nilai biomassa dan karbon tertinggi pada lokasi penelitian. Hasil penelitian menunjukkan bahwa kandungan karbon pada jaringan bawah substrat (akar dan rhizome) lebih tinggi dibandingkaan jaringan atas substrat (daun). Menurut Nordlund et al. (2016), rata - rata stok karbon 5,7\% diproduksi dari daun dan $28,3 \%$ diproduksi dibawah substrat dan disimpan dalam biomassa lamun hidup setiap tahun. Hasil estimasi kandungan karbon lamun dapat dilihat Tabel 3. dan Tabel 4.

Hasil penelitian menunjukkan karbon jaringan bawah substrat lebih tinggi dibandingkan atas substrat. Hal ini karena bagian bawah substrat minim terhadap gangguan lingkungan, sehingga karbon hasil fotosintesis dapat terakumulasi terus menerus. Gangguan lingkungan yang dimaksud yaitu daun lamun mudah patah/rusak karena gelombang dan arus, selain itu baling - baling pada perahu nelayan dapat merusak daun lamun. Menurut Latuconsina et al. (2014), bagian atas substrat lebih banyak termanfaatkan dalam rantai makanan dan terdekomposisi sehingga berpotensi tersimpan sedikit dalam substrat. Lamun melakukan fotosintesis dengan menyerap $\mathrm{CO} 2$ dan hasilnya adalah karbon $(\mathrm{C})$ dan oksigen $(\mathrm{O} 2)$, dimana oksigen dilepas pada lingkungan dan karbon disimpan dalam tubuh lamun sebagai biomassa. Menurut Runtuboi et al. (2018), biomassa disusun 45-50\% karbon. Penyimpanan hasil fotosintesis berada di bawah substrat dapat mendukung pertumbuhan lamun saat fotosintesis tidak optimum (Alcoverro et al, 2001).

Sedimen tempat lamun tumbuh adalah tempat penyimpanan karbon terbaik. Menurut Kennedy et al. (2009) kandungan karbon dibawah substrat akan tersimpan walaupun tunas pada lamun tersebut telah mati, sedangkan karbon diatas substrat hanya akan tersimpan jika tunas lamun masih hidup. Tipe substrat yang baik menyimpan karbon adalah lanau atau lempung karena memiliki tekstur lebih padat sehingga optimal mengikat karbon. Hasil penelitian menunjukkan bahwa kandungan karbon pada sedimen lebih sedikit dibandingkan pada lamun. Hal ini karena sedimen pada lokasi penelitian di dominasi tipe substrat pasir yang memiliki ukuran butir lebih besar, berongga dan ringan sehingga kurang padat. Tipe substrat ini mudah terbawa arus dan gelombang. Butiran substrat yang besar akan menurunkan kemampuan substrat tersebut menyerap karbon organik (Pratiwi, 2010). Christon et al. (2012), menambahkan bahwa besarnya biomassa lamun pada substrat lebih kecil diakibatkan oleh efek positiff terhadap sistem penyerapan nutrien.

Tabel 3. Estimasi Kandungan Karbon Lamun Perairan Alang - Alang

\begin{tabular}{cccc}
\hline \multirow{2}{*}{ Spesies } & & \multicolumn{2}{c}{ Total karbon perjaringan $\left(\mathrm{gbk} / \mathrm{m}^{2}\right)$} \\
\cline { 2 - 4 } & Bawah & Atas & Total \\
\hline Thalassia hemprichii & 8883,16 & 2349,29 & 11232,45 \\
Enhalus acoroides & 27566,34 & 7971,78 & 35538,12 \\
Cmodocea rotundata & 365,27 & 107,97 & 473,24 \\
Cymodocea serrulata & 1169,19 & 222,69 & 1391,88 \\
\hline
\end{tabular}

Tabel 4. Estimasi Kandungan Karbon Lamun Perairan Pancuran

\begin{tabular}{cccc}
\hline \multirow{2}{*}{ Spesies } & \multicolumn{3}{c}{ Total karbon perjaringan $(\mathrm{gbk} / \mathrm{m} 2)$} \\
\cline { 2 - 4 } & Bawah & Atas & Total \\
\hline Thalassia hemprichii & 12100,39 & 2209,00 & 14309,39 \\
Enhalus acoroides & 7768,08 & 752,76 & 8520,84 \\
Cymodocea rotundata & 2275,24 & 1313,26 & 3588,50 \\
Cymodocea serrulata & 40,25 & 20,06 & 60,30 \\
Halodule uninervis & 5,09 & 0,72 & 5,80 \\
Halophila ovalis & 12,17 & 6,90 & 19,07 \\
\hline \hline
\end{tabular}


Tabel 5. Estimasi Kandungan Karbon Sedimen Perairan Alang - Alang

\begin{tabular}{cc}
\hline Keterangan & Kandungan Karbon $\left(\mathrm{g} / \mathrm{m}^{2}\right)$ \\
\hline ALG/SEDIMEN/1 & 1,668 \\
ALG/SEDIMEN/2 & 1,581 \\
ALG/SEDIMEN/3 & 1,871 \\
\hline
\end{tabular}

Keterangan : ALG = Perairan Alang - Alang

Tabel 6. Estimasi Kandungan Karbon Sedimen Perairan Pancuran

\begin{tabular}{cc}
\hline Keterangan & Kandungan Karbon $\left(\mathrm{g} / \mathrm{m}^{2}\right)$ \\
\hline $\mathrm{PCR} /$ SEDIMEN/1 & 1,030 \\
$\mathrm{PCR} / \mathrm{SEDIMEN} / 2$ & 1,450 \\
$\mathrm{PCR} / \mathrm{SEDIMEN} / 3$ & 0,841 \\
\hline
\end{tabular}

Keterangan : PCR $=$ Perairan Pancuran

Hasil penelitian menunjukkan bahwa $T$. hemprichii, E. acoroides, dan $C$. rotundata memiliki kandungan karbon lebih tinggi dibandingkan sedimen, karena faktor kerapatan dan ukuran morfologinya. Selain itu faktor lingkungan juga mempengaruhi tingginya nilai karbon pada lamun. Berdasarkan penelitian yang dilakukan Graha (2015) di Pantai Sanur Bali memiliki kondisi lingkungan yang dipenuhi oleh aktivitas antropogenik manusia seperti pembuangan limbah dari hotel dan tambatan perahu wisata, sehingga memiliki nilai kandungan karbon lebih rendah dibandingkan hasil penelitian ini di Perairan Alang - alang dan Pancuran, karena Perairan Alangalang dan Pancuran belum terkena aktivitas antropogenik manusia yang tinggi. Menurut Nordlund et al. (2016), karbon organik yang dihasilkan oleh lamun tidak hanya didapat dari hasil tanaman dan sumber dari satu lokasi tersebut tetapi juga didapatkan dari nutrien yang terbawa oleh arus melalui peristiwa upwelling dari tempat lain. Ulqodry et al. (2010) menambahkan bahwa kandungan zat hara yang terdapat di perairan tidak hanya berasal dari perairan itu sendiri melainkan dari keadaan disekitarnya yang terbawa oleh gelombang dan arus.

\section{KESIMPULAN}

Biomassa lamun di Perairan Alang-Alang yaitu E. acoroides $1811,38 \mathrm{gbk} / \mathrm{m}^{2} ;$ T. hemprihii $473,23 \mathrm{gbk} / \mathrm{m}^{2}$; C. serrulata $123,08 \mathrm{gbk} / \mathrm{m}^{2}$ dan C. rotundata $25,72 \mathrm{gbk} / \mathrm{m}^{2}$, sedangkan di Perairan Pancuran yaitu E. acoroides $733,20 \mathrm{gbk} / \mathrm{m}^{2} ;$ T. hemprichii $510,11 \mathrm{gbk} / \mathrm{m}^{2} ;$ C. rotundata 160,48 $\mathrm{gbk} / \mathrm{m}^{2} ;$ C. serrulata $5,26 \mathrm{gbk} / \mathrm{m}^{2} ; H$. ovalis $2,47 \mathrm{gbk} / \mathrm{m}^{2}$ dan $H$. uninervis $0,47 \mathrm{gbk} / \mathrm{m}^{2}$. Kandungan karbon lamun di Perairan Alang - Alang yaitu E. acoroides $35.538,12 \mathrm{gC} / \mathrm{m}^{2} ; T$. hemprihii $11.232,45 \mathrm{gC} / \mathrm{m}^{2}$; C. serrulata $1.391,88 \mathrm{gC} / \mathrm{m}^{2}$; dan $C$. rotundata $473,24 \mathrm{gC} / \mathrm{m}^{2}$, sedangkan di Perairan Pancuran yaitu T. hemprichii $14.309,39 \mathrm{gC} / \mathrm{m}^{2}$; E. acoroides 8.520,84 gC/m ${ }^{2}$; C. rotundata $3588,50 \mathrm{gC} / \mathrm{m}^{2} ;$ C. serrulata $60,30 \mathrm{gC} / \mathrm{m}^{2} ; H$. ovalis $19,07 \mathrm{gC} / \mathrm{m}^{2}$, dan $H$. uninervis 5,80 $\mathrm{gC} / \mathrm{m}^{2}$. Kandungan karbon sedimen di Perairan Alang-Alang $1,581-1,871 \mathrm{gC} / \mathrm{m}^{2}$ dan di Perairan Pancuran $0,841-1,45 \mathrm{gC} / \mathrm{m}^{2}$.

\section{DAFTAR PUSTAKA}

Christon, O., Djunaedi, S. \& Purba, N.P. 2012. Pengaruh Tingginya Gelombang Pasang Surut Terhadap Pertumbuhan dan Biomassa Daun Enhalus acoroides di Pulau Pari Kepulauan Seribu Jakarta. Jurnal Perikanan dan Kelautan, 3(3):87-94.

Duarte, C.M. \& Cebrián, J., 1996. The fate of marine autotrophic production. Limnology and oceanography, 41(8):1758-1766. DOI: 10.4319/lo.1996.41.8.1758.

Duarte \& Chiscano, C.L. 1999. Seagrass Biomass and Production: a Reassessment. Aquatic Botany, 65(1):159-174. DOI : 10.1016/SO304-3770(99)00038-8.

Graha, Y.I. 2015. Simpanan Karbon Padang Lamun di Kawasan Pantai Sanur, Kota Denpasar. Ecotrophic, 10(1):46 53. DOI:10.24843/ejes.2016.v10.i01.p08. 
Hartati, R., Pratikto, I. \& Pratiwi, T.N. 2017. Biomassa dan Estimasi Simpanan Karbon pada Ekosistem Padang Lamun di Pulau Menjangan Kecil dan Pulau Sintok, Kepulauan Karimunjawa. Ilmu Kelautan, 17(4):217-225.

Latuconsina, H., Sangadji, M.B. \& Sarfan, L. 2014. Struktur Komunitas Ikan Padang Lamun di Perairan Wael Teluk Kontania. Jurnal IImiah Agribisnis dan Perikanan, 6(0):24-32. DOI : 10.29239/j.agrikan.6.0.24-32.

Mardiyanti, D.E., Wicaksono, K.P., Baskara, M. 2013. Dinamika Keanekaragaman Spesies Tumbuhan Pasca Pertanaman Padi. Jurnal Produksi Tanaman, 1(1):24-35.

Oreska, M.P.J., McGlathery, K.J., \& Porter, J.H. 2017. Seagrass with Blue Carbon Spatial Patterns at The Using A Meadow-Scale Methods. PloS ONE, 12(4):1-18. DOI: 10.1371/journal pone.0176630.

Phillips, R.C. \& Milchakova, N.A. Ekosistem Lamun (Seagrass Ecosystems). Jurnal Ekologi Kelautan, 2(2):29-39. DOI: 574.5:582.271/.275.

Pratiwi, R. 2010. Asosiasi Crustacea di Ekosistem Lamun Perairan Teluk Lampung. IImu Kelautan, 15(2):66-76. DOI: 10.14710/ik.jjms.15.2.66.76.

Rahadiarta, I., Vidyananda, S. \& Yulianto, S. 2019. Simpanan Karbon Org pada Padang Lamun di Kawasan Pantai Mengiat Nusa Dua Bali. Journal of Marine and Aquatic Sciences, 5(1):1-10. DOI: 10.24843/jmas.2019.v05.i01.p01.

Runtuboi, F., Nugroho, J. \& Rahakratat, Y. 2018. Biomassa dan Penyerapan Karbon oleh Enhalus Acoroides di Pesisir Teluk Gunung Botak Papua Barat. Jurnal Sumberdaya Akuatik Indopasifik. 2(2): 91-102.

Nordlund, L., Koch, E.W., Barbier, E.B. \& Creed, J.C. 2016. Seagrass Ecosystem Services and Their Variability Across Genera and Geographical Regions. PLOS ONE, 11(10):1-23. DOI: 10.1371/journal.pone 0163091 .

Tangke, U. 2010. Ekosistem Padang Lamun (Manfaat, Fungsi dan Rehabilitasi). Jurnal IImiah dan Perikanan, 3(1):1-21. DOI :10.29239/j.agrikan.3.1.9-29.

Tasabaramo, I.A., Kawaroe, M. \& Rappe, R.A. 2016. Laju Pertumbuhan, Penutupan Lamun, dan Tingkat Kelangsungan Hidup Enhalus acoroides yang di Transplantasikan Secara Monospesies dan Multispesies. Jurnal IImu dan Teknologi Kelautan Tropis. 7(2):757-770. DOI: 10.28930/jitkt.v7i2.11169.

Ulqodry, T.Z., Yulisman, Syahdan, M. \& Santoso. 2010. Karakteristik dan Sebaran Nitrat, Fosfat, dan Oksigen di Kepulauan Karimunjawa Jawa Tengah. Jurnal Penelitian Sains, 13(1):35-41. DOI: $10.26554 / j p s . v 13 i 1.162$. 